Article

\title{
The Effect of Exercise on Salivary Viscosity
}

\author{
Antoon J. M. Ligtenberg *, Erwin H. S. Liem, Henk S. Brand and Enno C. I. Veerman \\ Department of Oral Biochemistry, Academic Centre for Dentistry Amsterdam, 1081LA, Amsterdam, \\ The Netherlands; Erwinliem@hotmail.com (E.H.S.L.); h.brand@acta.nl (H.S.B.); e.veerman@acta.nl (E.C.I.V.) \\ * Correspondence: a.ligtenberg@acta.nl; Tel.: +31-20-5980896
}

Academic Editors: David Wong and Martin Weber

Received: 29 September 2016; Accepted: 8 November 2016; Published: 16 November 2016

\begin{abstract}
A common experience after exercise is the presence of a thick and sticky saliva layer on the oral surfaces, which causes a feeling of a dry mouth. Since the salivary mucin MUC5B is responsible for the visco-elastic behavior of saliva, in the present study we explored the effect of exercise on both the salivary viscosity and the secretion of MUC5B in saliva. Twenty healthy dental students performed an aerobic exercise by cycling for $15 \mathrm{~min}$ on cycle-ergometers at a heart rate of 130-140 beats per minute. Saliva was collected at three time points: before exercise, immediately after exercise and after $30 \mathrm{~min}$ recovery. Salivary flow rate, viscosity, amylase activity, total protein, carbohydrate and MUC5B concentration were determined. Salivary flow rate, protein and amylase did not change significantly. Immediately after exercise, the salivary viscosity and carbohydrate concentration were significantly higher than at baseline and after $30 \mathrm{~min}$ recovery. Immediately after exercise, the MUC5B concentration was significantly higher than after 30 min recovery. It is concluded that the presence of thick saliva after exercise is at least partially due to an increased secretion of MUC5B.
\end{abstract}

Keywords: exercise; MUC5B; amylase; protein

\section{Introduction}

Strenuous exercise has been associated with a reduced immune function and an increased susceptibility to infections, particularly of the upper respiratory tract (URTI) [1-5]. Exercise-related URTIs are associated with a decreased immune function at mucosal surfaces and a decreased secretion rate of salivary immune proteins [2]. Therefore, saliva has been used as a marker for mucosal immunity [6,7]. Saliva plays an important role in the body's first defense to ingested pathogens. It covers the hard and soft tissues in the oral cavity, forming a complex barrier that is important for hydration, lubrication, pathogen exclusion and resistance to proteolytic digestion. The high-molecular-weight mucin MUC5B comprises the matrix of this complex network and forms complexes with other innate immune components in saliva, including cystatins, histatins, immunoglobulins, proline-rich proteins and MUC7 [8,9].

Physical exercise has different effects on salivary parameters. After short, intense exercise, secretion of secretory IgA (s-IgA) decreased, whereas total protein increased [6]. With an exercise intensity above the anaerobic threshold, the secretion of total protein, amylase, lysozyme, lactoferrin, chromogranin A and MUC5B increased [10-14]. The increased secretion of proteins and immune components may be explained by the neuronal regulation of saliva secretion [15]. The salivary glands are both sympathetically and parasympathetically innervated. Parasympathetic stimulation elicits a high volume of watery saliva that is low in protein content. Saliva elicited by sympathetic stimulation is low in volume and high in protein content, mainly due to increased exocytosis of salivary proteins from salivary cells. The presence of elevated levels of salivary amylase is considered an indicator of increased adrenergic activity $[16,17]$. Since exercise is associated with enhanced sympathetic nervous 
system activation, it seems logical to assume that exercise will increase the secretion of several innate immune proteins.

After exercise, the salivary viscosity is increased, which may have several causes [18]. For example, dehydration with a concomitant decreased secretion rate of saliva may result in increased concentrations of proteins and mucins [19]. In addition, mouth breathing during exercise may lead to increased evaporation of water and subsequent thickening of saliva. Increased viscosity might also be due to the increased secretion rate of MUC5B, similar to the increased secretion of other proteins after exercise. A previous paper demonstrated that MUC5B secretion increased after intense exercise [14]. This was somewhat surprising, because MUC5B secretion is thought to be mediated by parasympathetic stimulation and intense exercise is a strong sympathetic stimulus [15].

In the present study we investigated the effect of exercise on saliva viscosity and the salivary mucin MUC5B. To exclude the potential effects of excessive mouth breathing and considerable changes in saliva above the anaerobic threshold, which may affect the viscosity of saliva, participants performed an aerobic exercise with moderate intensity. Participants exercised for $15 \mathrm{~min}$ on a cycle ergometer with a heart rate between 130-140 beats per minute [20], and the effects on the saliva secretion rate, viscosity, protein, carbohydrate, amylase and MUC5B were determined.

\section{Materials and Methods}

\subsection{Participants}

This study was approved by the Medical Ethical Committee of the VU Medical Center Amsterdam in accordance with OB13-453. Twenty healthy dental students of the Academic Centre for Dentistry in Amsterdam were recruited, 12 men and eight women aged 18-32 years (mean age $=25$ years). They were non-smokers and performed physical exercise at least two times a week. They were instructed beforehand about the research design and gave written informed consent.

\subsection{Experimental Procedure}

The subjects exercised on a cycle-ergometer with handgrip heart rate monitor (Life Fitness upright lifecycle 95C, T-Fitness, Amsterdam, The Netherlands) between 9:30 a.m. and 11:30 a.m. in a conditioned environment of $21.6^{\circ} \mathrm{C}$. They were instructed to refrain from doing strenuous physical activities $24 \mathrm{~h}$ before the test and not to eat or drink anything $1 \mathrm{~h}$ before the experiment. Each subject cycled for $15 \mathrm{~min}$ and was instructed to keep the heart rate between 130-140 beats per minute which was below the anaerobic threshold [20]. Unstimulated saliva was collected at three time points: before exercise, immediately after exercise and after a $30 \mathrm{~min}$ recovery period.

\subsection{Saliva Collection and Analysis}

Unstimulated saliva was collected by means of the spitting method [21]. Before collection, each participant was instructed not to breathe through the mouth or to talk during the collection of saliva. After swallowing all the saliva in the mouth, saliva was collected for $5 \mathrm{~min}$. Each participant expectorated in a disposable container every $30 \mathrm{~s}$. The samples were immediately put on ice after collection.

The volume of saliva was determined by weighing, assuming a density of $1.0 \mathrm{~g} / \mathrm{mL}$ for saliva. $\mathrm{pH}$ was measured with a pH meter (PHM240 pH/Ion Meter, Radiometer BV, Zoetermeer, The Netherlands).

\subsection{Viscosity Measurement}

Viscosity was measured with freshly collected saliva. Before viscosity measurements saliva was centrifuged $(1 \mathrm{~min}, 10,000 \times g)$ to remove cellular debris. The viscosity of the cleared saliva was measured with a viscometer (Vilastic 3, Vilastic Scientific Inc., Austin, TX, USA), as described 
previously [22]. The viscometer was calibrated before every measurement with demineralized water. Between measurements the tubings of the viscometer were flushed with demineralized water.

\subsection{Saliva Analysis}

Freshly collected saliva was diluted 1:1 with $150 \mathrm{mM} \mathrm{NaCl}$ and homogenized for 1 min with a Vortex mixer (Vortex-Genie, Wilten BV, Etten-Leur, The Netherlands). The dilution lowered viscosity, thus facilitating centrifugation and sample manipulation, and prevented protein aggregation and precipitation during saliva freezing and storage. Then saliva was clarified by centrifugation for $5 \mathrm{~min}$ at $10,000 \times g$ at room temperature. The cleared supernatants were stored at $-20{ }^{\circ} \mathrm{C}$ until use.

Protein concentration was determined using the Bicinchoninic Acid (BCA) protein assay (Pierce, Rockford, IL, USA) [23]. The amylase activity was measured with the EnzCheck Ultra Amylase Assay Kit (Thermo Scientific, Paisley, UK), using a fluorogenic starch substrate (DQ ${ }^{\mathrm{TM}}$ ) [23]. MUC5B concentration was determined as described previously with an anti sulfo-Lewis ${ }^{\mathrm{a}}$ monoclonal antibody F2 [23]. MUC5B concentration was expressed as units/mL. Unstimulated saliva of one person was used as a standard of one unit. Carbohydrate concentration was measured according to the method of Kilcoyne et al. [24]. $25 \mu \mathrm{L}$ saliva was mixed with $75 \mu \mathrm{L} 0.1 \%$ sodium meta periodate in $10 \%$ acetic acid in non-affinity microplates (Greiner) and incubated for $2 \mathrm{~h}$ at $37^{\circ} \mathrm{C}$. Thereafter, $100 \mu \mathrm{L}$ Schiff's reagent (Merck, Darmstadt, Germany) was added. After incubation for $1 \mathrm{~h}$ at $37^{\circ} \mathrm{C}$ color development was measured at $570 \mathrm{~nm}$ with a microplatereader (Thermo Scientific, West Palm Beach, FL, USA). $\mathrm{N}$-acetylgalactosamine $(0-2 \mathrm{mg} / \mathrm{mL})$ was used as a standard.

\subsection{Statistical Analysis}

The data collected at different time points were statistically compared by using the Friedman test for multiple related samples, using the Wilcoxon test as post-hoc procedure to compare the individual time points. IBM SPSS Statistics 21 (IBM, Armonk, NY, USA) for Windows was used for analyzing the data. Significance level was set at $p<0.05$.

\section{Results}

The effects of exercise on various salivary parameters are presented in Table 1. The salivary parameters that showed significant changes using the Friedman test for multiple related samples were subsequently compared pairwise with the Wilcoxon test. These results are shown in Table 2.

Table 1. Effect of exercise on the saliva flow rate, $\mathrm{pH}$, viscosity and composition of saliva. Values are mean \pm standard deviation.

\begin{tabular}{cccc}
\hline Time Point & Before Exercise & Immediately after Exercise & After 30 Min Recovery \\
\hline Saliva flow rate $(\mathrm{mL} / \mathrm{min})$ & $0.56 \pm 0.21$ & $0.58 \pm 0.20$ & $0.64 \pm 0.30$ \\
$\mathrm{pH}$ & $7.31 \pm 0.39$ & $7.32 \pm 0.44$ & $7.31 \pm 0.33$ \\
Viscosity $(\mathrm{mP} / \mathrm{s}){ }^{*}$ & $3.19 \pm 3.39$ & $3.86 \pm 3.78$ & $2.23 \pm 1.45$ \\
Protein concentration $(\mathrm{mg} / \mathrm{mL})$ & $1.18 \pm 0.41$ & $1.20 \pm 0.50$ & $1.15 \pm 0.39$ \\
Protein secretion rate $(\mathrm{mg} / \mathrm{min})$ & $0.63 \pm 0.26$ & $0.65 \pm 0.19$ & $0.71 \pm 0.36$ \\
MUC5B concentration (units/mL) & $1.28 \pm 0.94$ & $1.47 \pm 1.15$ & $0.92 \pm 0.68$ \\
MUC5B secretion rate (units/min) & $0.64 \pm 0.46$ & $0.75 \pm 0.49$ & $0.55 \pm 0.42$ \\
MUC5B/protein (units/mg) & $1.05 \pm 0.66$ & $1.16 \pm 0.64$ & $0.81 \pm 0.55$ \\
Carbohydrate concentration $(\mathrm{mg} / \mathrm{mL})$ & $1.23 \pm 0.40$ & $1.34 \pm 0.42$ & $0.76 \pm 0.51$ \\
Carbohydrate secretion rate $(\mathrm{mg} / \mathrm{min})$ & $0.65 \pm 0.18$ & $0.76 \pm 0.24$ & $1.18 \pm 0.53$ \\
Carbohydrate/protein $(\mathrm{mg} / \mathrm{mg})$ & $1.19 \pm 0.54$ & $1.27 \pm 0.41$ & $128 \pm 88$ \\
Amylase concentration (units/mL) & $128 \pm 74$ & $140 \pm 77$ & $83 \pm 70$ \\
Amylase secretion rate (units/min) & $73 \pm 55$ & $80 \pm 49$ & $106 \pm 57$ \\
Amylase/protein (units/mg) & $105 \pm 43$ & $120 \pm 56$ &
\end{tabular}


Table 2. Effect of exercise on the composition of saliva: comparison of different time points. Parameters that showed significant changes according to the overall comparison with Friedman test were post-hoc pairwise compared with the Wilcoxon test.

\begin{tabular}{ccccc}
\hline Overall Comparison & & \multicolumn{3}{c}{ Time Points Compared } \\
\cline { 3 - 5 } & & $\mathbf{1 - 2}$ & $\mathbf{1 - 3}$ & $\mathbf{2 - 3}$ \\
\hline Viscosity $(\mathrm{mP} / \mathrm{s})$ & $0.011^{*}$ & $0.040^{*}$ & 0.370 & $0.006^{*}$ \\
MUC5B concentration (units/mL) & $0.001^{*}$ & 0.104 & $0.008^{*}$ & $0.001^{*}$ \\
MUC5B secretion rate (units/min) & $0.026^{*}$ & 0.117 & 0.191 & $0.008^{*}$ \\
MUC5B/mg protein (units/mg) & $0.003^{*}$ & 0.086 & $0.030^{*}$ & $0.007^{*}$ \\
$\quad \begin{array}{c}\text { Carbohydrate concentration } \\
(\mathrm{mg} / \mathrm{mL})\end{array}$ & $0.006^{*}$ & 0.036 & 0.398 & $0.022^{*}$ \\
\hline
\end{tabular}

Time points: $1=$ before exercise; $2=$ immediately after exercise; $3=$ after 30 min recovery ${ }^{*} p<0.05$.

No significant differences were found in the $\mathrm{pH}$ and saliva flow rate. The protein concentration and secretion rate as well as the amylase concentration and secretion did not significantly change. The viscosity of saliva significantly increased immediately after exercise $(p=0.04)$ and decreased to sub-baseline values after 30 min recovery. Immediately after exercise, the MUC5B concentration and secretion rate were significantly higher than after 30 min recovery. The MUC5B concentration per mg protein was significantly decreased after 30 min recovery.

\section{Discussion}

An increase in salivary viscosity after exercise has been suggested before [18]. However, to our knowledge, this study is the first to demonstrate a significant increase in salivary viscosity directly after exercise. Since the salivary flow rate did not decrease during exercise, thickening of saliva due to mouth breathing or dehydration could not explain the observed increase in viscosity. Since MUC5B is the main determinant of salivary viscosity, we suggest that the increase in the MUC5B concentration causes the increase in salivary viscosity.

In previous studies, clear changes in the composition of saliva were reported when subjects exercised above the anaerobic threshold. Above the anaerobic threshold, amylase $[25,26]$, total protein [10], lactoferrin [27], chromogranin A [12], lactate [28], sodium and chloride all increased [6,29]. The present finding that exercise had no effect on the protein concentration is possibly due to the fact that the subjects exercised at a low to moderate intensity, well below the anaerobic threshold.

The saliva secretion rate is regulated by the synergistic actions of the parasympathetic and sympathetic nerves of the autonomic nervous system. The secretion of amylase and other proteins is evoked primarily by sympathetic stimulation. Mucin secretion has been suggested to be evoked primarily by parasympathetic stimulation of the sublingual and minor glands [15]. However, our study showed an increased MUC5B secretion rate immediately after moderate exercise. This increase was not significant, but in a previous study we showed a significant increase in MUC5B secretion immediately after moderate exercise [14]. Possibly, the cold air that is inhaled by mouth breathing during exercise stimulates mucus secretion by the minor glands in a similar way as in the lung epithelium [30]. This effect may have been stronger in the previous study where subjects exercised outdoors in colder circumstances $\left(7-15^{\circ} \mathrm{C}\right)$ than in the present study $\left(21.6^{\circ} \mathrm{C}\right)$.

\section{Conclusions}

In conclusion, this study shows that there is a temporary increase in the viscosity of saliva immediately after moderate exercise, which is probably caused by an increase of the MUC5B secretion rate.

Acknowledgments: This study was supported by the Academic Centre for Dentistry Amsterdam. We thank Jolanda Seijger for allowing us to use the facilities of the Sports Centre VU. 
Author Contributions: Antoon Ligtenberg designed the experiment, acquired the permission of the medical ethical committee, and wrote the paper. Erwin Liem performed the experiment and did the biochemical analysis of the saliva samples. Henk Brand supported the statistical interpretation. Enno Veerman assisted in writing.

Conflicts of Interest: The authors declare no conflict of interest.

\section{References}

1. Gleeson, M. Immune function in sport and exercise. J. Appl. Physiol. 2007, 103, 693-699. [CrossRef] [PubMed]

2. Gleeson, M.; Pyne, D.B. Exercise effects on mucosal immunity. Immunol. Cell Biol. 2000, 78, 536-544. [CrossRef] [PubMed]

3. Peters, E.M.; Bateman, E.D. Ultramarathon running and upper respiratory tract infections. An epidemiological survey. S. Afr. Med. J. 1983, 64, 582-584. [PubMed]

4. Nieman, D.C. Exercise, upper respiratory tract infection, and the immune system. Med. Sci. Sports Exerc. 1994, 26, 128-139. [CrossRef] [PubMed]

5. Heath, G.W.; Macera, C.A.; Nieman, D.C. Exercise and upper respiratory tract infections. Is there a relationship? Sports Med. 1992, 14, 353-365. [CrossRef] [PubMed]

6. Chicharro, J.L.; Lucia, A.; Perez, M.; Vaquero, A.F.; Urena, R. Saliva composition and exercise. Sports Med. 1998, 26, 17-27. [CrossRef] [PubMed]

7. Bishop, N.C.; Gleeson, M. Acute and chronic effects of exercise on markers of mucosal immunity. Front Biosci. 2009, 14, 4444-4456. [CrossRef]

8. Wickstrom, C.; Christersson, C.; Davies, J.R.; Carlstedt, I. Macromolecular organization of saliva: Identification of 'insoluble' MUC5B assemblies and non-mucin proteins in the gel phase. Biochem. J. 2000, 351, 421-428. [CrossRef] [PubMed]

9. Gibbins, H.L.; Proctor, G.B.; Yakubov, G.E.; Wilson, S.; Carpenter, G.H. Concentration of salivary protective proteins within the bound oral mucosal pellicle. Oral Dis. 2014, 20, 707-713. [CrossRef] [PubMed]

10. Bortolini, M.J.; De Agostini, G.G.; Reis, I.T.; Lamounier, R.P.; Blumberg, J.B.; Espindola, F.S. Total protein of whole saliva as a biomarker of anaerobic threshold. Res. Q. Exerc. Sport 2009, 80, 604-610. [CrossRef] [PubMed]

11. De Oliveira, V.; Bessa, A.; Lamounier, R.P.; de Santana, M.G.; de Mello, M.T.; Espindola, F.S. Changes in the salivary biomarkers induced by an effort test. Int. J. Sports Med. 2010, 31, 377-381. [CrossRef] [PubMed]

12. Bocanegra, O.L.; Diaz, M.M.; Teixeira, R.R.; Soares, S.S.; Espindola, F.S. Determination of the lactate threshold by means of salivary biomarkers: Chromogranin A as novel marker of exercise intensity. Eur. J. Appl. Physiol. 2012, 112, 3195-3203. [CrossRef] [PubMed]

13. Kunz, H.; Bishop, N.C.; Spielmann, G.; Pistillo, M.; Reed, J.; Ograjsek, T.; Park, Y.; Mehta, S.K.; Pierson, D.L.; Simpson, R.J. Fitness level impacts salivary antimicrobial protein responses to a single bout of cycling exercise. Eur. J. Appl. Physiol. 2015, 115, 1015-1027. [CrossRef] [PubMed]

14. Ligtenberg, A.J.; Brand, H.S.; van den Keijbus, P.A.; Veerman, E.C. The effect of physical exercise on salivary secretion of MUC5B, amylase and lysozyme. Arch. Oral Biol. 2015, 60, 1639-1644. [CrossRef] [PubMed]

15. Proctor, G.B.; Carpenter, G.H. Salivary secretion: Mechanism and neural regulation. Monogr. Oral Sci. 2014, 24, 14-29. [PubMed]

16. Chatterton, R.T., Jr.; Vogelsong, K.M.; Lu, Y.C.; Ellman, A.B.; Hudgens, G.A. Salivary $\alpha$-amylase as a measure of endogenous adrenergic activity. Clin. Physiol. 1996, 16, 433-448. [CrossRef] [PubMed]

17. Bosch, J.A.; Brand, H.S.; Ligtenberg, T.J.M.; Bermond, B.; Hoogstraten, J.; Nieuw Amerongen, A.V. Psychological stress as a determinant of protein levels and salivary-induced aggregation of Streptococcus gordonii in human whole saliva. Psychosom. Med. 1996, 58, 374-382. [CrossRef] [PubMed]

18. Dawes, C. The effects of exercise on protein and electrolyte secretion in parotid saliva. J. Physiol. 1981, 320, 139-148. [CrossRef] [PubMed]

19. Ljungberg, G.; Ericson, T.; Ekblom, B.; Birkhed, D. Saliva and marathon running. Scand. J. Med. Sci. Sports 1997, 7, 214-219. [CrossRef] [PubMed]

20. Droghetti, P.; Borsetto, C.; Casoni, I.; Cellini, M.; Ferrari, M.; Paolini, A.R.; Ziglio, P.G.; Conconi, F. Noninvasive determination of the anaerobic threshold in canoeing, cross-country skiing, cycling, roller, and ice-skating, rowing, and walking. Eur. J. Appl. Physiol. Occup. Physiol. 1985, 53, 299-303. [CrossRef] [PubMed] 
21. Navazesh, M. Methods for collecting saliva. Ann. N. Y. Acad. Sci. 1993, 694, 72-77. [CrossRef] [PubMed]

22. Van der Reijden, W.A.; Veerman, E.C.; Nieuw Amerongen, A.V. Shear rate dependent viscoelastic behavior of human glandular salivas. Biorheology 1993, 30, 141-152. [PubMed]

23. Prodan, A.; Brand, H.S.; Ligtenberg, A.J.; Imangaliyev, S.; Tsivtsivadze, E.; van der Weijden, F.; Crielaard, W.; Keijser, B.J.; Veerman, E.C. Interindividual variation, correlations, and sex-related differences in the salivary biochemistry of young healthy adults. Eur. J. Oral Sci. 2015, 123, 149-157. [CrossRef] [PubMed]

24. Kilcoyne, M.; Gerlach, J.Q.; Farrell, M.P.; Bhavanandan, V.P.; Joshi, L. Periodic acid-Schiff's reagent assay for carbohydrates in a microtiter plate format. Anal. Biochem. 2011, 416, 18-26. [CrossRef] [PubMed]

25. Akizuki, K.; Yazaki, S.; Echizenya, Y.; Ohashi, Y. Anaerobic threshold and salivary $\alpha$-amylase during incremental exercise. J. Phys. Ther. Sci. 2014, 26, 1059-1063. [CrossRef] [PubMed]

26. Calvo, F.; Chicharro, J.L.; Bandres, F.; Lucia, A.; Perez, M.; Alvarez, J.; Mojares, L.L.; Vaquero, A.F.; Legido, J.C. Anaerobic threshold determination with analysis of salivary amylase. Can. J. Appl. Physiol. 1997, 22, 553-561. [CrossRef] [PubMed]

27. West, N.P.; Pyne, D.B.; Kyd, J.M.; Renshaw, G.M.; Fricker, P.A.; Cripps, A.W. The effect of exercise on innate mucosal immunity. Br. J. Sports Med. 2010, 44, 227-231. [CrossRef] [PubMed]

28. Bardon, A.; Ceder, O.; Kollberg, H. Cystic fibrosis-like changes in saliva of healthy persons subjected to anaerobic exercise. Clin. Chim. Acta 1983, 133, 311-316. [CrossRef]

29. Chicharro, J.L.; Legido, J.C.; Alvarez, J.; Serratosa, L.; Bandres, F.; Gamella, C. Saliva electrolytes as a useful tool for anaerobic threshold determination. Eur. J. Appl. Physiol. Occup. Physiol. 1994, 68, 214-218. [CrossRef] [PubMed]

30. Li, M.; Li, Q.; Yang, G.; Kolosov, V.P.; Perelman, J.M.; Zhou, X.D. Cold temperature induces mucin hypersecretion from normal human bronchial epithelial cells in vitro through a transient receptor potential melastatin 8 (TRPM8)-mediated mechanism. J. Allergy Clin. Immunol. 2011, 128, 626-634. [CrossRef] [PubMed]

(C) 2016 by the authors; licensee MDPI, Basel, Switzerland. This article is an open access article distributed under the terms and conditions of the Creative Commons Attribution (CC-BY) license (http://creativecommons.org/licenses/by/4.0/). 